\title{
The Impact of Socioeconomic Factors and Financial Access on Microfinance Institutions
}

\author{
Moh'd Al-Azzam \\ Associate Professor of Economics \\ School of Business Administration, American University in Dubai \\ P.O. Box 28282, Dubai, U.A.E. \\ Tel: 971-4-318-3314 E-mail:malazzam@aud.edu \\ Karim Mimouni (Corresponding author) \\ Associate Professor of Finance \\ School of Business Administration, American University in Dubai \\ P.O. Box 28282, Dubai, U.A.E. \\ Tel: 971-4-318-3113E-mail: kmimouni@aud.edu

\begin{abstract}
Mohammed Abu Ali
Associate Professor of Economics

School of Business Administration, American University in Dubai
\end{abstract} \\ P.O. Box 28282, Dubai, U.A.E. \\ Tel: 971-4-318-3224 E-mail: mabuali@aud.edu
}

\author{
Received: December 28, 2011 \\ Accepted: January 16, $2012 \quad$ Published: April 1, 2012 \\ doi:10.5539/ijef.v4n4p61 \\ URL: http://dx.doi.org/10.5539/ijef.v4n4p61
}

\begin{abstract}
This paper is an attempt to unravel new factors that contribute to the success of microfinance institutions "MFIs." We investigate whether countrywide socioeconomic characteristics and financial access can impact MFIs' performance. Using data on 222 MFIs we find that countrywide socioeconomic characteristics such as fertility, income and education are important determinants of MFIs' performance. For example, profitability of MFIs is more likely to fall and default on loans is more likely to rise if fertility rate increases. We also find that countrywide financial access indicators have significant impact on MFIs' performance. For example, access to commercial banks deposit accounts has a significant and positive impact on MFIs' success. Access to loans and commercial banks outreach appear to have a negative impact on MFIs' performance. These results are important as they contradict the generally accepted assumption that commercial banks and MFIs operate in two different market segments and, hence, they are not direct competitors. Overall, the results suggest that several socioeconomic characteristics and financial access elements are important ingredients in evaluating MFIs' performance.
\end{abstract}

Keywords: Microfinance, Sustainability, Socioeconomic, Financial access

\section{Introduction}

Access to credit is seen as one strategy to reduce poverty in developing countries. Lack of collateral, cost of screening and monitoring, and cost of enforcing contracts are some factors that make lending to the poor unprofitable. In the past couple of decades, a growing number of financial institutions have developed alternative lending mechanisms reversing the conventional wisdom that lending to poor households is doomed to failure. Microfinance institutions (MFIs) provide small loans to poor households for starting productive business activities or expanding their current ones. The number of MFIs is estimated around 10,000 providing loans to more than 100 million small entrepreneurs worldwide. 
The cost of providing microfinance services is high due to the high costs of transaction and information. To cover these costs, a large number of MFIs still depend on donors' subsidies. Depending on subsidies however cannot guarantee the provision of microfinance services on a long-term basis. Financial sustainability of the MFIs therefore becomes a critical issue. Financial sustainability is broadly defined as the ability to cover cost without external subsidies from donors or governments. Given the role that microfinance can play in combating poverty, this paper evaluates some factors of success and failure that affect the sustainability of the MFIs. One strand of literature focuses on factors related to institution-specific characteristics and practices such as contract design, organizational structure, client targeting policies and management techniques. See for example Cull et al. (2007), Armendariz de Aghion and Morduch (2005), Kaboski and Townsend (2005), and Luzzi and Weber (2006). Another strand focuses on the effect of macroeconomic conditions, macro-institutional elements, and overall financial development on the MFIs' performance. See for example Honohan (2004), Ahlin et al. (2010), Hartarska and Nadolhyak (2007), and Gonzales (2007).

The effect of countrywide socioeconomic factors on MFIs' performance has been overlooked in the literature. Microfinance institutions operate in different countries with diverse socioeconomic environments. We specifically investigate the following questions: Do socioeconomic factors matter for MFIs' performance? Is it easier for an MFI to grow within a more educated society? Does income per capita have any implications on the MFIs' performance? Do MFIs perform differently depending on the religion of the country? Do MFIs grow faster or slower if borrowers families are large?

Despite the perception that making loans to the poor is a bad debt, returns to MFIs rival those of commercial banks. High return on lending to the poor has convinced commercial banks such as Citigroup and Deutsche Bank that the poor are no longer un-bankable. Large commercial institutions are now showing more interest in microfinance which increases the poor's access to credit. While the effect of county-level financial environment on MFIs has been investigated in the literature, this paper seeks to understand the consequences of using different set of relevant financial indicators on MFIs. More specifically, this paper considers the effect of the expansion of commercial banks and therefore the diffusion of financial services on MFIs performance.

The effects of socioeconomic factors and commercial bank expansion on MFIs' performance do not have absolute answers in economic theory. We believe that different components of socioeconomic factors and different indicators of financial access may affect MFIs' performance in different directions. This paper empirically investigates the nature of direction of these relationships.

The rest of the paper is organized as follows. Section 2 provides an overview of related literature. Section 3 describes estimation methodology. Data and variables used are discussed in section 4. For readability and smoothness reasons, the priori expectations and the empirical results are presented together in Section 5. Section 6 provides limitations to this study and section 7 contains concluding remarks.

\section{Literature Review}

There is a significant literature on financial performance and financial efficiency of MFIs. Yaron (1994) devised what is called the Subsidy Dependence Index (SDI) to indicate the minimum level of interest rate charged to borrowers in order for the institution to cover all operating costs. Using this index, Hulme and Mosley (1996) showed that the vast majority of the institutions in their sample were still dependent on subsidy. Similarly, Morduch (1999) showed that if Grameen Bank had to pay 15.3\% for loans in 1996 then Grameen would have to charge its borrowers a nominal interest rate of at least $40 \%$.

Chaves and Gonzalez-Vega (1996) examined the factors of success of the Rural Financial Intermediaries (RFIs) in Indonesia. They concluded that the RFIs who have the financial resources but lack access to the required information and contract information tools can take advantage of local agents who have inexpensive access to information and monitoring by recruiting them with a system of compatible incentives.

Armendariz de Aghion and Morduch (2005) put together the conventional and controversial issues surrounding subsidies. Acknowledging the fact that subsidies can be a good investment, the authors expressed some concerns; proper usage of the subsidy, reliance on subsidies that limit the scale of operation, donors' strong push for financial sustainability has forced some MFIs to devise innovations to reduce subsidies suggesting that the cost-benefit analysis may overstate the benefits of subsidies, and the eventual "donor fatigue" when subsidies disappear as donors choose to move on.

Cull et al (2007) pioneered the use of cross-country and cross-MFI data. The data set contains 56 individual lenders, 48 group-based lenders and 20 village banks drawn from 49 countries. They found that raising interest rates to very high levels does not guarantee higher profitability or cost minimization. Up to a certain level, profitability of 
individual-based lenders that charge higher interest rates is larger than others. Beyond that threshold interest rate, profitability falls because of greater loan defaults and falling demand for credit. In contrast, financial performance of group-based lenders does not improve as interest rates increase. They found that individual-based lenders with higher cost of labor are more profitable. According to the authors, individual-based lenders are careful about selecting and monitoring customers which required more labor force. For group-based lenders, who use local information to select and monitor borrowers, they found that labor costs had no significant impact on their profitability.

Using data for 435 MFIs over the period 1997-2007, Hermes et al (2009) investigated the relationship between financial development and MFIs efficiency. The authors find that more developed financial systems contribute to more efficient MFIs. Generally, efficiency gains are attributed to competitive pressure that stimulates MFIs to diversify their financial services and to spell-over effects.

In a more recent work, Ahlin et al (2010) use data on 373 MFIs and merge it with more than 70 country-level economic and institutional data. They found that economic growth has a significant and beneficial impact on MFIs performance and that MFIs in more financially developed economies are associated with lower operating costs, lower default rates, and lower interest rate, suggesting that competition benefits micro-borrowers. They also documented the adverse impact of labor force participation rates and the share of manufacturing in the economy on the growth of the MFIs. The authors' overall results suggest that the country macroeconomic and institutional environments are important determinants of MFIs performance.

Our paper differs from the literatures in its emphasis on some new factors that may affect MFIs sustainability. First, it focuses on the effects of the countrywide socioeconomic conditions that are overlooked in the literatures. Second, it uses a new set of financial indicators to examine the nature of the relationship between MFIs performance and commercial banks expansion.

\section{Estimation Methodology}

The estimation Methodology of this paper follows Ahlin et al (2010). Let $y_{i j t}$ be a year- $t$ outcome of MFI $i$ located in country $j ; M_{i t}$ be a set of MFI-specific control variables at time $t ; X_{j t}$ be a set of socioeconomic factors describing country $j$; and $Z_{j}$ be a set of financial access proxies for country $\mathrm{j}$ at time t. Following Ahlin et al (2010), we also include a set of macroeconomic variables. Let $W_{j t}$ be a set of macroeconomic variables capturing country $j$ at time $t$. The baseline specification is

$$
y_{i j t}=a_{1}+\alpha_{2} M_{i t}+\alpha_{3} X_{j t}+\alpha_{4} Z_{j}+\alpha_{5} W_{j t}+\varepsilon_{i j t} .
$$

This specification pools all MFIs and estimates. The outcome of the MFIs is measured using four variables; operational self-sufficiency, sufficiency index, write-of-ratio and at risk ratio. The MFI control variables include a quadratic in age and institutional legal status dummies. The socioeconomic factors include a quadratic lagged per capita GDP (income), education index, fertility rate, and the main religion in each country. The financial access factors include access to deposits, deposits capacity, loan access, loan liability, and commercial bank outreach. The macroeconomic variables include annual growth in real GDP, manufacturing value added, workforce measured as labor force to population aged 15-64, foreign direct investment as percentage of the GDP, and inflation.

Similar to Ahlin et al (2010), we estimate conditional median functions rather than conditional mean functions. This is because errors may be correlated with MFIs and outlier problems can be potentially severe. Coefficient estimates of the conditional median functions minimize the sums of absolute residuals rather than the sum of squared residuals. Conditional median functions tend to be less susceptible to outlier problems compared to least squares. To account for within MFI standard errors correlations, we use bootstrap standard errors, clustering by institution. We use 1000 repetitions.

\section{Data and Variable Description}

We use the microfinance institution data from Mix Market. This organization provides financial performance data from microfinance institutions worldwide, as well as some business information from market facilitators and leading donor organizations and investors in the microfinance field. The data is available online on exchange Mix Market (www.mixmarket.org).

We select the data based on their level of reliability. To do so, we only include MFIs with four and five diamonds. Mix Market classifies the MFIs into five diamond categories according to the reliability of the data. The MFIs rated with four and five diamonds provide the most reliable data. Our dataset includes observations from 2000 to 2008 
with a minimum of five observations or more for each of the four dependent variables. Therefore, for every MFI's performance variable, we require having at least five observations during the period 2000 to 2008 .

Description of the variables and summary statistics are provided in Table 1. We use four variables to proxy for the MFI performance; operational self-sufficiency $(O S S)$, sufficiency index $(S I)$, write-off-ratio $(W O R)$ and at-risk-ratio $(A R R)$. The first two variables measure profitability while the other two measure risk. Operational self sufficiency is the ratio of annual financial revenue to annual total expense. The higher this ratio is, the better the performance of the MFIs to meet their expenses and to generate profits. Sufficiency-index is the ratio of financial revenue to total expense plus financial revenue.

The write-off-ratio is the average value of loans written-off during a year to the average gross loan portfolio. This ratio indicates the magnitude of losses of MFIs due to unpaid loans and is therefore a proxy for financial risk. Finally, the at-risk-ratio is defined as the values of loans unpaid for more than 30 days to the average gross loan portfolio. While the first risk ratio proxies for realized losses, the second focuses on expected losses.

The MFI control variables include the institutional type and the age of the MFI. This data is also obtained from the Mix Market. The age of the MFI is the number of years since it was established $(A G E)$. We include age and its square to control for the fact that the relationship between age and MFIs performance may change over time. To control for the fact that different types of MFIs may have different levels of profitability and risk, we consider four institutional-type dummies: banks, Non-Government Organizations (NGO), Non-Banking Institutions (NBI) and Credit Unions $(C U)$. We use banks as the base institutional type.

This paper also investigates the effect of socioeconomic factors on MFIs. To do so we select a set of variables that shows the overall countrywide socioeconomic characteristics. These variables include a quadratic in lagged per capita GDP (INCOME); an education index (EDUCATION), and average fertility per female (FERTILITY). The education index used is for 2007. According to the Human Development Report the education index is defined as "Mean of years of schooling for adults aged 25 years and expected years of schooling for children of school going age. Mean years of schooling is estimated based on duration of schooling at each level of education (for details see Barro and Lee, 2010). Expected years of schooling estimates are based on enrolment by age at all levels of education and population of official school age for each level of education. The indicators are normalized using a minimum value of zero and maximum values are set to the actual observed maximum values of the indicators from the countries in the time series, that is, 1980-2010. The education index is the geometric of two indices." Another socioeconomic variable used is the religion of the borrower which may impact commitment to repay the debt. We include three dummies to indicate the main religion of country $j$; CHRISTIAN, MUSLIM or HINDU. In our sample, almost $60 \%$ of MFIs are located in Christian countries, $26 \%$ in Muslim countries, $7 \%$ in Hindu countries and $7 \%$ in countries with other religions such as Buddhism. Other religions are used as the base religion. Data on income per capita and fertility rate, education index, and religion are obtained from World Bank, the United Nation 2010 Human Development Report, and from the Association of Religion Data Archives respectively. Data used for income per capita, fertility rate and religion cover the period 2000-2008. Data used for education is only for the year 2007.

One important research question in this paper is the impact of borrowers' access to commercial banking on the performance of MFIs. Data on financial access are obtained from the Consultative Group to Assist the Poor (CGAP) 2009's report. The CGAP collected the first set of indicators of financial access in countries around the world in 2005 and updated these indicators for selected countries in 2008. Building on this work, Financial Access in its first annual series of 2009 introduces new data from a survey of financial regulators in about 139 countries. It includes indicators of access to savings, credit, and payment services in banks and regulated non-bank financial institutions. Variables used to proxy for financial access to commercial banks are access to deposit (DEPOSIT ACCESS), deposits capacity (DEPOSIT CAPACITY), loan access (LOAN ACCESS), loan liability (LOAN LIABILITY), and commercial bank outreach (CB-OUTREACH). Access to deposits is defined as the number of deposits opened with commercial banks per 1000 adults; deposit capacity is the average deposit balance divided by per capita income; loan access is the number of loans given by commercial banks per 1000 individuals; loan liability is the average loan balance divided by per capita income; and commercial bank outreach is number of bank branches per 100,000 adults.

Given the evidence of complementarities between MFI performance and the broader economy found by Ahlin et al (2010), we include annual growth rate in real GDP (GDP GROWTH), manufacturing value added (MANUFACTURING), workforce measured as the labor force to the population aged 15-64 (WORKFORCE), foreign direct investment as a percentage of the GDP (FDI), and inflation (INFLATION); same as those used by Ahlin et al (2010). The country-level data were obtained from the 2010 World Development Indicators Report. 


\section{Results}

The results are reported in Tables 2 and 3. Table 2 reports the main regression results with respect to the effect of the countrywide socioeconomic and financial access variables on MFIs' profitability and risk ratios. The combined effects including macroeconomic variables are reported in Table 3. Table 3 corroborates Ahlin et al. (2010) findings that reveal the importance of macroeconomic environment in understanding and evaluating the success of MFIs.

\subsection{Control Variables}

Similar to those found by Ahlin et al (2010), the results show that there is an evidence of learning curve effect. An increase in the age of the MFIs initially improves profitability. After a turning point, at an age of 18 years in our study, a further increase in age worsens MFIs' profitability. The overall results indicate that the type of the MFI matters. Unsurprisingly, the overall results show that credit unions types of MFIs have higher profitability than non-profit counterparts.

\subsection{Socioeconomic Factors}

This section discusses our a priori expectations and the empirical results on the effect of different socioeconomic aspects on MFIs' profitability and risk.

Income: For low income countries, the demand for microfinance services is expected to be high. Also, at low income levels, an increase in income is expected to increase the demand for goods and services produced by microenterprises. These two factors may therefore help MFIs to thrive. In richer economies, however, the demand for microfinance services is expected to be low and the demand for goods and services produced by microenterprises are expected to be low as people move away toward higher quality goods and services generally produced by large and well established firms. Growth of MFIs is therefore expected to be limited in richer economies. The relationship between per capita income and MFIs' performance therefore is expected to be nonlinear. To capture this nonlinearity we include INCOME and its square root INCOME2.

While the signs on INCOME and INCOME2 are consistent with our expectations in both tables, the results in Table 2 show that income level has no significant impact on profitability and risk factors of MFIs. In the full model in Table 3, income has a statistically significant impact on MFIs through its effect on the write-off-ratio. As income, INCOME, increases from low levels the ratio of unpaid loans to total loan portfolio falls. A further increase in income (INCOME2) seems to increases the risk variables but the effect is statistically insignificant. We also considered the linear function of INCOME. The effect of INCOME was found to be statistically insignificant in all models. In general, these results moderately corroborate our expectations according to which MFIs face more uncertainty in relatively richer economies.

Education: The impact of education on MFIs' sustainability does not have a definite answer. On one hand, we would expect the demand for microfinance services to fall as potential borrowers get more educated. More education increases the chance of getting employed by either the public or private sector and increases access to commercial banks that offer larger loans at lower interest rates than MFIs. Potential borrowers with higher education are therefore expected to be less credit rationed; have less unfulfilled demand for credit. Consequently, commitment of the more educated borrowers for loan repayment from MFIs might be less than the commitment of the less educated borrowers with higher unfulfilled demand for credit. These factors may negatively impact the MFIs sustainability. On the other hand, within MFIs' borrowers, more educated people are expected to be more productive in their microenterprises which strengthen their ability in loan repayment. Higher repayment rates induced by more educated borrowers may improve MFIs sustainability. In terms of signs, the overall results on EDUCATION in Tables 2 and 3 seem to favor the first explanation. Education shows a positive and statistically significant impact on only the unpaid loans of the MFIs, WOR. The results suggest that the need of microfinance services and the commitment for loan repayment among the less educated borrowers may actually help the MFIs growing faster.

Religion: MFIs do not provide grants to the poor; they provide loans at significantly higher interest rate than those provided by commercial banks. It is legitimate at this point to ask if differences in religion beliefs of borrowers have any impact the MFIs' sustainability. Lending at interest or excessive interest has been intensely criticized on religious grounds. Old Hinduism and Buddhism expressed sentiments of contempt for interest rate. Currently, while condemned in principle, interest charged above the prevailing range is no longer prohibited or controlled in any significant way in both Hinduism and Buddhism. Early Christianity started out by prohibiting interest on lending. Increasingly thereafter Christianity allowed acceptable levels of interest rate; however, an excessive rate has not been acceptable. The criticism of interest rate in Islam was well established and prohibited in the Holy Quran but the interpretation of interest rate has not been universally accepted or uniformly applied in the Islamic countries (Visser and MacIntosh (1998)). Demand for microfinance loans can therefore be reduced based on religious prescriptions 
and this may affect MFIs sustainability. Religion beliefs can also affect the sustainability of the MFIs by encouraging borrowers to be productive in their enterprises and by assuming honest intention in repaying the debt.

In general, the results in Tables 2 and 3 show that the religion dummies are not strong predictors of the MFIs profitability and risk. Except for the positive and significant effect of MUSLIM on the at-risk-ratio, the differences in the effect of religion on all other dependent variables are statistically insignificant. An explanation of the positive effect of MUSLIM on the at-risk-ratio may lie in the following: In Islam borrowing at non-zero interest rate is prohibited. However, such Islamic law is usually not applied in most Islamic countries. This may reduce the demand for MFIs services by the relatively religious potential borrowers and may affect the performance of some MFIs. In fact, to alleviate this potential problem, some MFIs attempt not to explicitly use the concept of interest and refer to it as "cost of borrowing" or as "administrative fees" instead. For some MFIs to expand, they may need to take some more risk and be more lenient in terms of late repayment which increases at-risk-ratio.

Fertility: Fertility could be an indication of the magnitude of financial obligations on the family head which reduces the family's repayment capacity. On the other hand, larger family size could also indicate the availability of free family-labor to utilize the microcredit loans. This reduces the cost of running a micro-enterprise and enhances the family repayment capacity and therefore the MFIs' profitability. Therefore, the relationship between fertility and MFIs is not straightforward. The average number of children per female, FERTILITY, shows a negative and statistically significant impact on MFIs' profitability and a positive and statistically significant impact on MFIs' risk. The results suggest that higher rates of fertility thwart MFIs' sustainability. Fertility might be a drain for micro-enterprise profit due to the increase in households' consumption and the reduction in their repayment capacity and consequently the MFIs' sustainability.

This result can be of particular interest knowing that seven out of ten microfinance clients worldwide are women. See for example Daley-Harris (2003). Indeed, the results in part may provide a rationale of the women-empowerment's mission carried out by many MFIs through fertility reduction. Microfinance programs may affect fertility decision by increasing the opportunity cost of women's time; urging them to reduce family size in order to increase education and health expenditures and improve their repayment performance. Pitt et al (2003), Da Vanzo and Mizanur (1998), and Armendariz and Roome (2008) are among many studies that examine the relationship between MFIs and women empowerment. To the best of our knowledge, this paper is the first to record the effect of fertility on MFIs' sustainability.

\subsection{Financial Access}

This section discusses our a priori expectations and the empirical results on the effect of different financial indicators on MFIs' profitability and risk.

Deposit Access: Results in tables 2 and 3 show that DEPOSIT ACCESS and DEPOSIT CAPACITY both have positive and statistically significant impact on MFIs' profitability but show no effect on risk variables. The fact that more deposit access and capacity improve the MFIs' profitability seems inconsistent. Indeed, we would expect lower income individuals to have greater access to commercial bank deposit services as these become widely available. Put differently, the MFIs' share of the deposit services provided and their profitability are expected to fall as the penetration of commercial bank deposit service rises. However, it is important to notice that deposit services are usually directed to the relatively higher income clients, not to the poor. Microfinance industry has focused its attention in providing loans to the poor with little emphasis in expanding deposit services. In fact, more than 80 percent of deposit services are provided by commercial banks. Cooperative, specialized state financial institutions, and microfinance institutions provide around 20 percent. Microfinance institutions hold only about 1 percent of deposits, concentrated mostly in developing countries as documented by the CGAP 2009 report.

How then can one explain the positive impact of commercial bank deposit access on MFIs' profitability? We offer two possible explanations. First, the availability of deposit services in a country is influenced by some factors including the overall level of economic activities, economic development and trust in the financial system. All these factors may play a positive and an important role on the profitability of the MFIs. In this, deposit access can be thought as an indicator of the overall macroeconomic conditions that may positively impact the MFIs' performance. Second, the increase in access to deposit services and deposit capacity both reduce the amount of loans provided by the informal moneylenders to the poor leaving the MFIs with a larger population of borrowers to serve. Greater deposit access may siphon away potential borrowers from the informal moneylenders which increases the demand for the MFIs' loans and enhances the MFIs' profitability.

The positive impacts of deposit access and deposit capacity on MFIs' profitability support the findings of both Ahlin et al (2010) and Hermes et al (2009) that financial development complements MFIs' performance. 
Loan Access: We would expect commercial banks to start offering loans to the relatively richer clients and then move to lower income clients as they expand. An increase in the access of lower income clients to loans from commercial banks leads borrowers to substitute their loans from MFIs for loans from commercial banks. Lower borrowing costs, larger loan sizes, and more borrowing options provided by commercial banks divert borrowers from MFIs to commercial banks. This substitution effect reduces the demand for loans from the MFIs which in turn reduces the MFIs' profitability. In addition to this, an increase in loan access with larger loans by the poor allows them to get multiple loans from different financial institutions which may have negative impact on their repayment performance with the MFIs. Lower repayment rates by borrowers would reduce profitability of the MFIs. Our results show that the effects of LOAN ACCESS and LOAN LIABILITY on profitability measures are all negative as expected in both Tables 2 and 3. Except for the effect of LOAN ACCESS on the first profitability measure in Table 3, however, the effect of the loan access variables are not statistically significant.

While LOAN ACCESS shows significant and positive impact on the risk of the MFIs, LOAN LIABILITY unexpectedly shows significant and negative impact on the MFIs' risk variables. More access to loans is expected to increase the MFIs' risk for two possible reasons. First, as mentioned above, an increase in loan access reduces MFIs repayment rates and increases MFIs' risk. Second, MFIs might be forced to take more risk and be more aggressive in lending as they face more competitive environment. The effect of LOAN LIABILITY on the risk variables, however, seems to be counter intuitive. The overall results on LOAN ACCESS and LOAN LIABILITY suggest that the expansion of commercial banks hamper the sustainability of the MFIs.

Commercial Banking Outreach: The effect of $C B$-OUTREACH on profitability measures is negative and statistically significant in both Models 2 and 3. The effect of $C B$-OUTREACH on the risk variables is statistically insignificant. The results on the outreach of commercial banks support the general theme that competition reduces profit. As commercial banks' penetration, in terms of the number of bank branches per 1000 adults, increases, MFIs' profits fall.

Results on credit and commercial bank outreach contradict the general conclusion by Ahlin et al (2010) and Hermes et al (2009) that financial development complements MFIs. Our results show that different financial indicators can have different effects on the performance of the MFIs. For example, our results suggest that while access to deposit in commercial banks has positive impact on MFIs' profitability, access to loans from commercial banks and commercial bank outreach both have negative impacts on MFIs' performance. We believe that the overall effect of financial development on MFIs' performance needs further analysis.

\subsection{Macroeconomic Variables}

While the emphasis of this paper is not on the effect of the broader economy on MFIs' performance, we believe it is crucially important to include macroeconomic features in our model. Ahlin et al (2010) and Ahlin and Lin (2006) find that the success of MFIs is significantly affected by the macroeconomic environment. They found an evidence of complementarities between MFIs performance and the broader economy. In Table 3, we include similar macroeconomic variables to those used in Ahlin and Lin (2006). We use the original macroeconomic variables used by Ahlin and Lin (2006).

The overall results in Table 3 validate Ahlin et al (2010) findings. This is most obvious in the effect of growth in GDP on both profitability and risk variables, $O S S$ and $A R R$.

\section{Limitations}

While this paper establishes a significant relationship between socioeconomic variables and MFIs' performance and between the degree of financial access and MFIs' performance, it still has some limitations: First, the causal effect of socioeconomic factors and financial access cannot be perfectly established. For example, strong MFIs can be thought as a source of improving socioeconomic factors and enhance the demand for commercial banking services. However, given the small size of the MFIs reverse causality would be implausible. For example, while MFIs may affect fertility and income of its clients, it is unlikely to affect these variables at the national level given that MFIs clients usually make small part of the overall population. By the same token, we can ask whether a sound microfinance sector increases the income of its clients and therefore increases the access to formal financial sector. Once again it is unlikely for this to happen given the small size of the MFIs' borrowers relative to the overall pool of borrowers served by the formal financial sector. Second, we believe that omitted variable bias is still a problem. The range of factors that lead to a sound MFI can be vast; degree of credit rationing, methodology of lending (group vs. individual), diversification of financial services provided, gender target, and the use of technology are among many of these factors. Studying the impact of these variables may lead to possibly more interesting results. Finally, the main focus of this paper is to examine the importance of socioeconomic and financial access factor in evaluating MFIs' performance, not to draw policies. 


\section{Conclusion}

Given the role that microfinance can play in combating poverty, this paper evaluates some components of success and failure that affect the sustainability of the MFIs. In particular, it evaluates the effects of socioeconomic and financial access factors on MFIs' performance using two hundred and twenty two MFIs worldwide.

This paper highlights an interesting relationship between socioeconomic factors and the performance of MFIs. The most evident and prominent among those is the negative impact of fertility on the MFIs' performance. Higher fertility rate of borrowers increases their consumption needs and financial obligations which lead to slower growth in MFIs. Even though the evidence is not as strong, education appears to increase the MFIs' risk in terms of unpaid loans while income reduces it.

While borrowers' access to deposits, and deposits capacity appear to improve MFIs' sustainability, borrowers' access to loans, loans liability and commercial bank outreach appear to worsen sustainability. This result raises an important question. Does financial development complement or rival MFIs? Our paper suggests that different aspects of financial development have different effects on MFIs performance. For example, access to deposit may reflect the overall economic activity and trust in the financial system, which in return may help MFIs' expansion and sustainability. Also, the participation of commercial banks in wholesale lending to the MFIs would help MFIs' expansion. On the other hand, commercial banks outreach and access to loans are found to hinder MFIs' sustainability.

In conclusion, we believe that, among other factors, the overall socioeconomic and access to formal banking are imperative in understanding and evaluating MFIs performance.

\section{References}

Ahlin, C., \& Lin, J. (2006). Luck or Skill? MFI Performance in Macroeconomic Context. Working Paper 132: BREAD.

Ahlin, C., Lin, J., \& Maio, M. (2010). Where Does Microfinance Flourish? Microfinance Institution Performance in Macroeconomic Context. Journal of Development Economics, 95, 2, 105-120. http://dx.doi.org/10.1016/j.jdeveco.2010.04.004

Armendariz de Aghion, B., \& Morduch, J. (2005). The Economics of Microfinance: The MIT Press.

Armendariz, B., \& Roome, J. (2008). Gender Empowerment in Microfinance. Typescript: Harvard University.

Chavis, R., \& Gonzalez-Vega, C. (1996). Design of Successful Rural Financial Intermediation: Evidence from Indonesia. World Development, 24, 65-92. http://dx.doi.org/10.1016/0305-750X(95)00114-R

Cull, R., Demiorguc-Kunt, A., \& Morduch, J. (2007). Financial Performance and outreach: A Global Analysis of Leading Microbanks. Economic Journal, 117, 107-133. http://dx.doi.org/10.1111/j.1468-0297.2007.02017.x

Daley-Harris, S. (2003). State of the Microcredit Summit Campaign Report 2003. Microcredit Summit Campaign: Washington, D.C.

Gonzalez, A. (2007). Resilience of Microfinance Institutions to National Macroeconomic Events: An Econometric Analysis of MFI Asset Quality. The MicroBanking Bulletin, 14, 36-38.

Hartarska, V., \& Nadolnyak, D. (2007). Do Regulated Microfinance Institutions Achieve Better Sustainability and Outreach?. Applied Economics, 39, 1207-1222. http://dx.doi.org/10.1080/00036840500461840

Hermes, N., Lensink, R., \& Meesters, A. (2009). Financial Development \& the Efficiency of Microfinance Institutions, Working paper: University of Groningen.

Honohan, P. (2004). Measuring Microfinance Access: Building on Existing Cross-Country Data, World Bank Policy Research. Working Paper, 3606: World Bank.

Hulme, D., \& Mosley, P. (1996). Finance Against Poverty. Vols. 1 \& 2, London: Routledge.

Kaboski, J., \& Townsend, R. (2005). Policies and Impact: An Analysis of Village-Level Microfinance Institutions. Journal of European Economic Association, 3, 1-50. http://dx.doi.org/10.1162/1542476053295331

Luzzi, F., \& Weber., S. (2006). Measuring Performance of Microfinance Institutions. Microfinance and Public Policy, 9, 153-169.

Morduch, J. (1999). The Role of Subsidies in Microfinance: Evidence from the Grameen Bank. Journal of Development Economics, 60, 229-248. http://dx.doi.org/10.1016/S0304-3878(99)00042-5

Pitt, K., \& Cartwright, J. (2003). Does Microcredit Empower Women? Evidence from Bangladesh, The World Bank Policy Research, Working Paper, 2998: World Bank. 
Da Vanzo, J., \& Mizanur, R. (1998). Influence of the Grameen Bank on Contraceptive Use in Bangladesh. Population Council: New York.

Visser, W., \& MacIntosh, A. (1998). A Short Review of the Historical Critique of Usury. Accounting, Business and Financial History, 8, 175 - 189. http://dx.doi.org/10.1080/095852098330503

Yaron, J. (1994). What Makes Rural Finance Institutions Successful?. World Bank Economic Review, 9, (1), 1909-1926.

Table 1. Variables Description and Summary Statistics.

\begin{tabular}{|c|c|c|c|c|c|c|c|}
\hline Variable & Obs & Description & Mean & Std. dev. & Median & $\begin{array}{l}25 \text { th } \\
\text { percentile }\end{array}$ & $\begin{array}{l}\text { 75th } \\
\text { percentile }\end{array}$ \\
\hline $\begin{array}{l}\text { OPERATING SELF } \\
\text { SEFFICIENCY (OSS) }\end{array}$ & 1307 & $\begin{array}{l}\text { Financial revenue / (Financial expense }+ \text { Loan loss } \\
\text { provision expense }+ \text { operating expense) }\end{array}$ & $121.83 \%$ & $41.78 \%$ & $117.78 \%$ & $103.03 \%$ & $135.91 \%$ \\
\hline $\begin{array}{l}\text { SUFFICIENCY INDEX } \\
\text { (SI) }\end{array}$ & 1307 & $\begin{array}{l}\text { Financial revenue / (Financial expense }+ \text { Loan loss } \\
\text { provision expense }+ \text { operating expense }+ \text { Financial } \\
\text { revenue) }\end{array}$ & $53.62 \%$ & $7.90 \%$ & $54.08 \%$ & $50.75 \%$ & $57.61 \%$ \\
\hline $\begin{array}{l}\text { WRITE-OF RATIO } \\
\text { (WOR) }\end{array}$ & 1256 & $\begin{array}{l}\text { Annual value of loan written off / annual average } \\
\text { gross loan portfolio }\end{array}$ & $1.70 \%$ & $4.20 \%$ & $2.81 \%$ & $0.00 \%$ & $1.75 \%$ \\
\hline At risk ratio (ARR) & 1358 & $\begin{array}{l}\text { Value of loans at-risk }>30 \text { days / annual average } \\
\text { gross loan portfolio }\end{array}$ & $4.97 \%$ & $7.85 \%$ & $2.81 \%$ & $0.01 \%$ & $0.06 \%$ \\
\hline INCOME & 1416 & Real GDP per $\quad(1000$ s of constant $2000 \$)$ & 1.32 & 0.04 & 1.00 & 0.40 & 2.02 \\
\hline EDUCATION & 1416 & Education composite index 2007 & $76.45 \%$ & $16.23 \%$ & $88.10 \%$ & $64.30 \%$ & $89.10 \%$ \\
\hline MUSLIM & 1416 & $\begin{array}{l}\text { Dummy that takes } 1 \text { if the main religion of the } \\
\text { country is Islam }\end{array}$ & -- & -- & -- & -- & -- \\
\hline CHRISTIAN & 1416 & $\begin{array}{l}\text { Dummy that takes } 1 \text { if the main religion of the } \\
\text { country is Christianity }\end{array}$ & -- & -- & -- & -- & -- \\
\hline HINDU & 1416 & $\begin{array}{l}\text { Dummy that takes } 1 \text { if the main religion of the } \\
\text { country is Hinduism }\end{array}$ & -- & -- & -- & -- & -- \\
\hline FERTILITY & 1416 & Average number of children per female & 3.17 & 1.27 & 2.84 & 2.39 & 3.64 \\
\hline DEPOSIT ACCESS & 1328 & $\begin{array}{l}\text { Number of Deposit accounts opened with } \\
\text { Commercial Banks per } 1,0000 \text { adults }\end{array}$ & 560.36 & 453.36 & 516.90 & 273.70 & 716.40 \\
\hline DEPOSIT CAPACITY & 1248 & Average deposit balacnce / per capita income & 221.29 & 219.30 & 165.50 & 62.50 & 259.10 \\
\hline LOAN ACCESS & 1019 & $\begin{array}{l}\text { Number of loans with Commercial Banks per } \\
1,0000 \text { adults }\end{array}$ & 160.73 & 158.92 & 71.60 & 38.30 & 349.00 \\
\hline LOAN LIABILITY & 908 & Average loan balacnce / per capita income & $2,427.33$ & $6,042.65$ & 632.90 & 141.50 & $1,374.60$ \\
\hline CB-OUTREACH & 1402 & Number of bank branches per 100,000 adults & 10.57 & 13.51 & 7.50 & 4.00 & 11.60 \\
\hline GDP GROWTH & 1416 & Annual growth rate in real GDP & $5.17 \%$ & $4.58 \%$ & $4.55 \%$ & $2.67 \%$ & $7.22 \%$ \\
\hline MANUFACTURING & 1407 & Manufacturing vaue added ( $\%$ of GDP) & $15.38 \%$ & $5.39 \%$ & $15.93 \%$ & $13.55 \%$ & $18.12 \%$ \\
\hline WORKFORCE & 1416 & Labor force / Population aged 15-64 & $72.53 \%$ & $9.32 \%$ & $72.61 \%$ & $66.48 \%$ & $77.10 \%$ \\
\hline FDI & 1416 & $\begin{array}{l}\text { Net Foreign direct investement inflows ( } \% \text { of } \\
\text { GDP) }\end{array}$ & $4.25 \%$ & $6.04 \%$ & $2.79 \%$ & $1.16 \%$ & $5.00 \%$ \\
\hline INFLATION & 1415 & Annual consumer price inflation & $7.28 \%$ & $6.68 \%$ & $5.80 \%$ & $3.42 \%$ & $9.09 \%$ \\
\hline
\end{tabular}

Notes: We provide summary statistics for the dependent variables and for the independent variables used in our regressions for the period 2000 to 2008. We also provide the description of each variable. 
Table 2. Baseline (Pooled) Results

\begin{tabular}{|c|c|c|c|c|c|c|c|c|}
\hline & \multicolumn{3}{|c|}{ Profitability } & \multicolumn{5}{|c|}{ Risk } \\
\hline & \multicolumn{2}{|l|}{ OSS } & \multicolumn{2}{|l|}{ SI } & \multicolumn{2}{|l|}{ WOR } & \multicolumn{2}{|r|}{ ARR } \\
\hline & Estimate & Stadard & Estimate & Stadard & Estimate & Stadard & Estimate & Stadard \\
\hline & & Error & & Error & & Error & & Error \\
\hline \multicolumn{9}{|l|}{ Control Variables } \\
\hline $\mathrm{AGE}$ & $2.362 * * *$ & 0.489 & $0.501^{* * *}$ & 0.127 & 0.0114 & 0.021 & 0.103 & 0.064 \\
\hline AGE2 & $-0.0606 * * *$ & 0.013 & $-0.0129 * * *$ & 0.003 & 0.000164 & 0.001 & 0.00179 & 0.002 \\
\hline $\mathrm{CU}$ & $15.77^{*}$ & 8.467 & $3.192 * *$ & 1.618 & -0.581 & 0.419 & -1.387 & 0.872 \\
\hline "NBI & " & 1.136 & 2.849 & 0.0381 & 0.544 & -0.157 & 0.199 & -0.753 \\
\hline NGO & $-10.29 * * *$ & 3.582 & $-2.228 * * *$ & 0.774 & $-0.404 * *$ & 0.205 & -1.117 & 0.727 \\
\hline \multicolumn{9}{|c|}{ Socioeconomic Variables } \\
\hline INCOME & -1.172 & 6.172 & -0.135 & 1.288 & -0.277 & 0.256 & -0.941 & 0.604 \\
\hline INCOME2 & -0.329 & 0.714 & -0.113 & 0.179 & 0.0343 & 0.041 & 0.0989 & 0.073 \\
\hline EDUCATION & 0.0211 & 0.213 & 0.00281 & 0.046 & $0.0137 * *$ & 0.006 & 0.00861 & 0.021 \\
\hline MUSLIM & 4.795 & 7.044 & 1.085 & 1.307 & 0.119 & 0.467 & $2.195 * * *$ & 0.666 \\
\hline CHRISTIAN & 8.512 & 6.193 & 1.561 & 1.438 & 0.241 & 0.415 & 1.479 & 1.064 \\
\hline HINDU & -14.06 & 10.740 & -3.014 & 1.912 & 0.0217 & 0.402 & 0.0193 & 0.654 \\
\hline FERTILITY & $-7.940 * * *$ & 1.960 & $-1.586 * * *$ & 0.457 & 0.13 & 0.100 & $1.095 * * *$ & 0.348 \\
\hline \multicolumn{9}{|c|}{ Financial Access Variables } \\
\hline DEPOSIT ACCESS & 0.0418 & 0.027 & 0.00832 & 0.006 & -0.000707 & 0.001 & 0.000948 & 0.001 \\
\hline DEPOSIT & $0.0353 * *$ & 0.015 & $0.00733 * *$ & 0.003 & 0.000426 & 0.001 & 0.00201 & 0.001 \\
\hline \multicolumn{9}{|l|}{ CAPACITY } \\
\hline LOAN ACCESS & -0.0385 & 0.037 & -0.00611 & 0.009 & $0.00245^{*}$ & 0.001 & $0.0104 * * *$ & 0.004 \\
\hline LOAN LIABILIT & $-1.84 \mathrm{E}-04$ & 4.92E-04 & $-3.32 \mathrm{E}-05$ & $1.12 \mathrm{E}-04$ & $-3.67 \mathrm{E}-05$ & $1.82 \mathrm{E}-05$ & $-7.29 \mathrm{E}-05$ & $7.08 \mathrm{E}-05$ \\
\hline CB-OUTREACH & $-1.011 * *$ & 0.455 & $-0.205^{* *}$ & 0.096 & 0.00328 & 0.009 & -0.0241 & 0.022 \\
\hline CONSTANT & $111.7^{* * *}$ & 22.800 & $52.66^{* * *}$ & 4.750 & -0.757 & 1.056 & $-4.820 * *$ & 2.300 \\
\hline $\mathrm{N}$ & 823 & & 823 & & 789 & & 856 & \\
\hline
\end{tabular}

Notes: In each column we run a median regression using the profitability and risk as dependent variables. The significance level used are $10 \%, 5 \%$ and $1 \%$ denoted by $* * *$, and $* * *$ respectively. 
Table 3. Baseline (Pooled) Results with Macroeconomic Variables

\begin{tabular}{|c|c|c|c|c|c|c|c|c|}
\hline & \multicolumn{3}{|c|}{ Profitability } & \multicolumn{4}{|c|}{ Risk } & \\
\hline & \multicolumn{2}{|l|}{ OSS } & \multicolumn{2}{|l|}{ SI } & \multicolumn{2}{|l|}{ WOR } & \multicolumn{2}{|l|}{ ARR } \\
\hline & Estimate & Standard error & Estimate & Standard error & Estimate & Standard error & Estimate & Standard error \\
\hline \multicolumn{9}{|l|}{ Control Variables } \\
\hline AGE & $1.954 * * *$ & 0.578 & $0.411 * * *$ & 0.136 & 0.038 & 0.028 & $0.124 *$ & 0.071 \\
\hline AGE2 & $-0.0541 * * *$ & 0.014 & $-0.0115^{* * *}$ & 0.003 & -0.00053 & 0.001 & 0.00142 & 0.002 \\
\hline $\mathrm{CU}$ & $17.28 * *$ & 8.319 & $3.933 * *$ & 1.614 & -0.299 & 0.415 & $-2.007 *$ & 1.035 \\
\hline NBI & 0.803 & 3.192 & 0.152 & 0.574 & -0.12 & 0.214 & -0.94 & 0.662 \\
\hline NGO & $-9.432 * *$ & 3.905 & $-2.229 * *$ & 0.949 & $-0.399^{*}$ & 0.211 & $-1.326^{*}$ & 0.710 \\
\hline \multicolumn{9}{|c|}{ Socioeconomic Variables } \\
\hline INCOME & 10.7 & 8.498 & 2.498 & 1.877 & $-0.687 *$ & 0.368 & -1.114 & 0.680 \\
\hline EDUCATION & -0.2 & 0.249 & -0.0428 & 0.057 & $0.0232 * * *$ & 0.008 & 0.0154 & 0.026 \\
\hline MUSLIM & 7.858 & 7.191 & 1.734 & 1.161 & 0.123 & 0.433 & $1.595^{* *}$ & 0.764 \\
\hline CHRISTIAN & 10.48 & 7.019 & 2.004 & 1.482 & 0.278 & 0.473 & 0.313 & 1.027 \\
\hline HINDU & -5.449 & 13.830 & -0.783 & 2.634 & -0.352 & 0.398 & 0.428 & 0.920 \\
\hline FERTILITY & $-9.671 * * *$ & 2.808 & $-2.217 * * *$ & 0.576 & 0.15 & 0.119 & $1.226 * * *$ & 0.365 \\
\hline \multicolumn{9}{|c|}{ Financial Access Variables } \\
\hline DEPOSIT ACCESS & $0.0465 *$ & 0.027 & 0.00824 & 0.005 & -0.000465 & 0.001 & -0.00176 & 0.002 \\
\hline DEPOSIT CAPACITY & $0.0335^{* *}$ & 0.016 & $0.00610^{* *}$ & 0.003 & 0.00042 & 0.001 & 0.000588 & 0.001 \\
\hline LOAN ACCESS & $-0.0725 *$ & 0.041 & -0.0146 & 0.010 & $0.00282 *$ & 0.002 & $0.0176^{* * *}$ & 0.005 \\
\hline LOAN LIABILITY & $-4.80 \mathrm{E}-04$ & $5.26 \mathrm{E}-04$ & $-1.15 \mathrm{E}-04$ & $1.31 \mathrm{E}-04$ & $-1.52 \mathrm{E}-05$ & $2.21 \mathrm{E}-05$ & $-1.68 \mathrm{E}-05$ & $8.76 \mathrm{E}-05$ \\
\hline CB-OUTREACH & $-0.979 * *$ & 0.495 & $-0.181 *$ & 0.104 & -0.00677 & 0.014 & 0.0425 & 0.029 \\
\hline \multicolumn{9}{|c|}{ Macroeconomic Variables } \\
\hline GDP GROWTH & $0.747 * *$ & 0.376 & 0.121 & 0.087 & -0.00611 & 0.020 & $-0.148 * *$ & 0.067 \\
\hline MANUFACTURING & -0.569 & 0.874 & -0.16 & 0.174 & 0.00473 & 0.015 & $0.0837^{*}$ & 0.0482 \\
\hline WORKFORCE & 0.641 & 0.404 & $0.156^{*}$ & 0.094 & $-0.0255^{*}$ & 0.016 & 0.0414 & 0.034 \\
\hline FDI & -0.231 & 0.420 & -0.0671 & 0.090 & -0.000183 & 0.016 & $-0.115^{* * *}$ & 0.042 \\
\hline INFLATION & -0.0932 & 0.307 & -0.028 & 0.066 & 0.000219 & 0.005 & 0.0079 & 0.032 \\
\hline CONSTANT & $85.91 * *$ & 42.430 & $47.83 * * *$ & 8.489 & 0.386 & $(1.412)$ & $-8.248 * *$ & 3.643 \\
\hline $\mathrm{N}$ & 823 & & 823 & & 789 & & 856 & \\
\hline
\end{tabular}

Notes: In each column we run a median regression using the profitability and risk as dependent variables. The significance level used are $10 \%, 5 \%$ and $1 \%$ denoted by $*, * *$, and $* * *$ respectively. 